The Japanese Journal of Animal Psychology 40-1, 2-17 (1990)

$\overline{\text { 総 説 }}$

\author{
行動の適応と進化 \\ 一 行動研究における生態学的アプローチー \\ 筑波大学 藤 田統

\section{Adaptation and Evolution of Behavior: An Ecological Approach to the Study of Behavior} \\ OSAMU FuJITA \\ University of Tsukuba
}

\begin{abstract}
I
かって，エソロジー（動物行動学）の創始者 の一人である Tinbergen (1963) は, 行動研究 には答えるべき四つの問題があると述べた。第 一が行動のメカニズムに関する問題，第二が行 動の個体発生に関する問題, これは心理学でい えば発達の問題である。第三が行動の機能 (function), すなわち行動の適応 (adaptation) に関係する問題，最後が行動の進化に関する問 題であった。
\end{abstract}

このうち第一と第二は「行動はどのような仕 組みで生じるのか」という行動のメカニズムを 問題にしているので，それらを Alcock（1975） は How Question と呼び，また，Sociologyを 書いた Wilson (1975) は Proximate factor (直 接因）と名づけた。それに対して第三と第四は 「行動はなぜ現にあるような姿なのか」という ことを問題にしているから，これらを Alcock は Why Question と呼び, Wilson は Ultimate factor (究極因) と名づけた。このように，動物

本稿は, 平成 2 年 9 月 16 日早稲田大学で開催さ れた日本動物心理学会第 50 回大会における特別 講演「行動の適応と進化」をまとめたものである。
行動の研究には解決すべき問題に 2 種類のもの があり, 研究者によってその関心の方向も大き く二つに分かれることになる。

動物行動を研究する心理学者が最も関心を 持ってきた学習の問題についても, How と Why の分け方をすることができる。How Questionでは，学習はどういうメカニズムで起こる かを追求し, Why Question では，なぜ学習は あるのか, あるいは, 動物が自分の生態学的環 境の中で生き抜くためには，何を学習する必要 があるかを追求する。

しかし，これまでの伝統的心理学では，生体 の行動を研究しながらも，もっぱら How Questionのみに関心が集中し, Why Question はほ とんど無視されてきたといっても過言ではな い。筆者はこれまで Why Question の重要性を 強調してきたが(藤田, 1983 a, b, 1984 a, 1985 ： 藤田・加藤, $1983 \mathrm{a}, \mathrm{b})$, 心理学でのこうした観 点からの研究は, わが国では試みられることが 少なかった。

ところが近年, 心理学の研究分野においても, 生態学的アプローチ (ecological approach) と 呼ばれるアプローチが興隆してきた。このアプ ローチは, Why Question を正面からとりあげ, なによりも行動の適応性を重視するところに特 
徵がある。その結果, 最近では, 伝統的アプロー チの色彩の濃い学習の分野においてすら, 生態 学的アプローチに基づいた著書が出るように なった (Johnston \& Pietrewicz, 1985; Bolles \& Beecher, 1988; Davey, 1989; Dewsbury, 1990)。

その理由としては, 心理学においても行動の 適応・進化という観点の重要性がようやく認識 され始めたことが背景にあるが, 現実には伝統 的な学習心理学の枠組みでは説明のできない実 験データが増えてきたこと, さらには, 生態学 的分脈で初めて意味を持つ学習が続々と発見さ れてきたことが挙げられよう。そこで，まず学 習理論を例にして, 生態学的アプローチと伝統 的アプローチの違いを述べてみたい。

まず，これまでの伝統的学習理論の特徵は， 異なる種, 異なる刺激, 異なる反応, 異なる強 化子を越えた一般性 (generality) を追求してき たところにある。そこでは，得られた一般法則 はどんな種に対しても, ぞんな刺激, 反応, 強 化子に対しても適用できるものと考元られた。 つまり，種，刺激，反応，強化子には，それぞ れ任意な互換性 (任意性, arbitrariness) がある と考元られたわけである。

ところが, 1970 年頃から伝統的な学習理論の 枠組みには納まらない実験室デー夕が増えてき た。更に，生態学的分脈で初めて意味を持つ学 習が発見され，その意義が認識されるように なった。こうした初期の動向のうち有名なもの を 4 つ挙げてみるならば, Garcia \& Koelling

（1966）の味覚嫌悪学習と Brown \& Jenkins (1968) の自動形成 (auto-shaping) の研究があ り, Bolles (1970) の種特異的防御反応 (SSDR) と Seligman (1970) の学習の準備性 (prepardness)の理論がある。そして,こうした研究の流 れは, 生物学的制約 (biological constraints) という名の下にまとめられ，伝統的学習理論の 根底を摇さぶるものとして発展して行ったので ある。

生物学的制約は，当初考元られた以上に，は
るかに強いショックを伝統的学習理論に及ぼし た。そのため今日では, 伝統的学習理論の牙城 はすでに崩壊したのだと宣言する研究者すらい る (Bolles, 1985)。しかし，それにしても今に なって考元るならば，生物学的制約という名称 は, 現在, 生態学的アプローチと呼ばれるよう になった新しいアプローチの本来の思想を正し くは示していなかったと思う。

なぜなら，彼らが発見したことが一般性に対 する単なる「制約」なのであれば，それは例外 に過ぎないのであるから，一般理論の中へ組み 込んでしまえば伝統的学習理論は安泰というこ とになるからである。事実, 1970～1980 年代に おける伝統的学習理論側の努力は, 生物学的制 約をいかにして一般法則の中に統合するかとい う理論再構成への努力であったといえよう（例 えば, Logue, 1979 ; LoLordo, 1979)。

\section{II}

しかしながら, 生態学的アプローチが提出し ている問題は，これまでの伝統的アプローチが 持っていた世界観，あるいは思想とは基本的に 異なるものである。Table 1 は, 伝統的アプロー チと生態学的アプローチが, 動物, 環境, 刺激, 反応についてどのように考元ているかを, 筆者 なりに比較してみたものである。

Table 1 伝統的アプローチと生態学的アプローチ の比較

\begin{tabular}{l|l|l}
\hline & 伝統的アプローチ & \multicolumn{1}{|c}{ 生態学的アプローチ } \\
\hline 動物 & 種を越えた抽象的存在 & 種としての特異性を持つ存在 \\
環境 & 個体をとりまくもの & 種と行動を作りだしてきたもの \\
(無生態学的) & 次世代を作りだしているもの \\
刺激 & 単なる物理量 \\
反応 & 生態学的に意味のある験変数の一つ & \\
個体が刺激 \\
(任意的特性) \\
思想
\end{tabular}


まず，動物については，伝統的アプローチで は, 動物とは行動のメカニズムに関する一般法 則を得るための実験材料に過ぎなかった。それ ゆえに、一般法則を導き易い動物でさえあれば, それがラットであってもハトであっても，どの ような動物種であってもよかった。この点で, 伝統的アプローチは，生物というものを抽象的 な存在として捉えるという致命的な誤りを犯し ていたといえる。

これに対して, 生態学的アプローチでは, 動 物とは進化の歴史の中で種として作られてきた ものであり，それ故に，それぞれの種が環境に 適応してきた結果として, 特色ある種特異性を 備えていることを重視する。刺激への感受性も 反応の種類も, どういうことを学習しやすいか, しにくいかということにも，それぞれに種特殊 性があると考える。この点が，伝統的アプロー チと大きく相違するところである。

次に環境については, 筆者は伝統的アプロー チでは，環境というものをほとんど考えてこな かったのだと思う。もちろん，伝統的アプロー チでも環境に言及している。しかし，彼らが考 えた環境とは単に個体を取りまくものに過ぎな かった。それぞれの種にはそれぞれ固有の生態 学的環境があるということは, ほとんど頭に浮 ばなかったのだと思う。

このために, 彼らは動物を自然環境から切り 離しても, 少しも違和感がなかった。確かに実 験室にも動物を取りまくものはあるのだから, 彼らの考えた環境は存在する。だからこそ, 動 物の生態学的環境とは全く似てもつかない実験 条件を平気で設定できたのであろう。

ところが, 生態学的アプローチでは, 環境と は進化の流れにおける自然選択の主役として, その種の行動を作りだしてきたものとして位置 づける。しかも，今の動物が示している行動を 判定することで, 次世代の存続を左右するもの でもある。動物はそうした中で生活し, 個体の 維持と種の保存を図って行かなければならない のである。
刺激については，伝統的アプローチでは，刺 激とは単なる物理量であり, 実験変数の一つに 過ぎなかった。従って任意に取り替えることが できるし，任意に操作できるものと考えられて きた。しかし, 生態学的アプローチでは, 刺激 とはあくまでも生態学的な意味を持った環境の 一部なのであるから,それぞれの種にとっては, もともと意味のある刺激と, 意味のない刺激が あり,そう任意に取り替えられるものではない。

反応についても，伝統的アプローチでは，反 応とはそれぞれの個体に属するものとして考え てきた。だから，実験に当たっては，それがバー 押し反応であれ，走行反応であれ，とにかく一 般理論形成のために便利な反応でさえあれば, それを任意に選ぶことに対して，なんら抵抗を 感じなかった。しかし, 生態学的アプローチで は, 反応とはもともと進化の歴史の中で種に備 わってきたものであるから，それぞれの種にお いて特異的であり, 適応的であり,さらに個体 が示す諸反応も，その生物学的意義において等 価ではないと考えられている。

以上の比較から分るように, 生態学的アプ ローチが基づく思想とは, 進化論的世界観であ る。従って, 自然選択の結果として生じた行動 の適応性を正面から取り上げる。この点で, 還 元主義的世界観に基づいた伝統的アプローチ が，行動の適応性を無視してきたことと極めて 対照的であるといえる。

\section{III}

そこで,ここで改めて, 心理学の研究対象で ある行動とは一体どういったものなのか，つま り, 行動とは生体にとってどのような意義を持 つものかを考えてみたい。

Fig. 1 は, ヨーロッパにいる 2 種のケラの雄 が掘る穴の形である。このどちらの種の雄も, 穴の中で翅をこすりあわせて鳴き声を出し，そ れを聞いた雌が穴に入ってきて交尾をする。し たがって,このケラの雄にとっていま一番大事 なことは, 自分の鳴き声をうまく穴の外に出し 

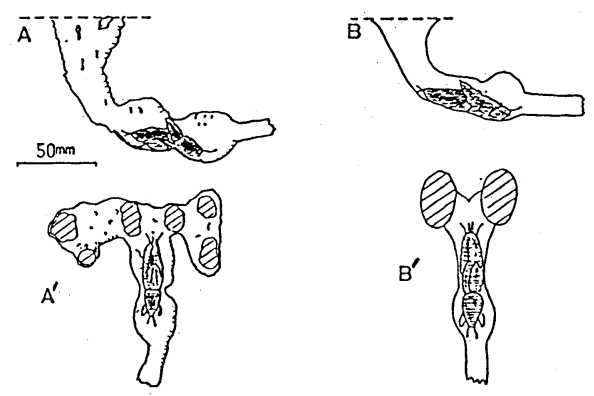

Fig. 12 種のケラの雄が掘る穴の形 (Bennet-Clark, 1970a) Aと $\mathrm{A}^{\prime} は G$. gryllotalpa, B と $\mathrm{B}^{\prime}$ は G. vineae

て雌を引きつけ, 交尾し, その結果, 自分の遺 伝子を残すことである。

ところが，見て分かるように，この 2 種では 穴の形が大きく違っている。横から見た場合に は一方の種ではこぶが一つだけだが，他方の種 ではこぶが二つある。また，上から見ると，一 方の種では穴の出口が二つだが，もう一方の種 では沢山ある。もちろん, それぞれの種の雄は, どの雄も自分の種に独特の穴を掘る。

Bennet-Clark（1970 a, b) は，2 種のケラの 穴と同じ模型を作り，中でいろいろの振動数の 音を鳴らして, どの振動数の音が最もよく穴の 形に共鳴して，外へ出ていくかを実験した。そ の結果, 2 種のケラの雄の鳴き声は振動数が異 なるのだが，どちらの種の穴の形も，鳴き声が 最も効率よく穴の外へ出る形になっていたので ある。また，ケラは穴の一定の位置に頭をおき， 奥の方を向いて鳴く。このことについても Bennet-Clark は音を鳴らす位置を変えて調心゙ たところ, 最も効率よく音が外へ出て行く位置 で鳴いていることが分かった。

そこでいま，ケラの雄が自分の遺伝子を残す ための最も効率のよい行動を考えてみると，少 なくともまず種に特有の穴を掘り，穴の中の決 まった位置で，しかも穴の奥の方を向き，自分 の種に特有の振動数の鳴き声を出すことが必要 である。この中のどれか一つがうまくできなく
ても，例えば，穴の形を変に掘っても，奥へ行 きすぎても，声が小さくても，鳴き声は効率よ く穴の外へ出て行かない。雌はもっとうまく やった雄の方へ行ってしまって, 失敗した雄は 自分の遺伝子を残すことができない。

では，どの行動が一番大事かというと，実は 個々の行動の効果は互いに補いあうことができ る。穴を少々変に掘っても, 大きな声で鳴けば いいし, 鳴き声が少々弱くても, 穴を見事に掘っ ていれば，声はうまく穴から出て行く。要は， 最終的に, 穴の外にいる雌に魅力的な声がどれ だけうまく届くかが重要なのである。

藤田 (1983 a) はそれを行動の最終効果と呼ん だが, いくつかの行動のまとまりとして生じた 最終効果が,ケラにとって一番重要だといえる。 従って, 自然選択（この場合には雌による選択） が作用するのは，いま言った最終効果に対して であり，個々の行動に対してではない。そして その自然選択の結果として，最終効果を支えて いた各行動，更にはその行動を支えていた各構 造や器官のメカニズムが, 判定されることにな る。

すなわち,生体には脳や神経系も含めて,様久 な構造や器官やメカニズムがあるものの, それ らはすべて行動を支えるためにある。そして， 総合戦力としての行動が, 個体の最終手段とし て環境へ働きかけ，自然選択の判定を受けるの である。こうして，「生きもの」が持つ 2 つの大 きな目的，すなわち，個体の生命維持と種の保 存は, 行動によって初めて達成される。個体は 「行動」によって餌を入手し，「行動」によって 捕食者から逃げ，「行動」によって卵子と精子を 合体させねばならない。

長年にわたって自然選択は，行動という形で 個体が示す最終効果を判定することで，ダー ウィン適応度 (Darwin fitness) のより高い行 動を残してきた。ここでいう適応度 (fitness) とは,「ある個体が一生のうちで，どれだけ自分 と同じ遺伝子を残せたか」ということで示され る尺度である。自分と同じ遺伝子という意味は， 
Hamilton(1964)が考えた包括適応度 (inclusive fitness）を意味し，行動が適応的か否かという ことは, 最終的には適応度で示されなければな らない。

こうして，自然選択を遺伝子レベルで考える ならば，それはある遺伝子型を持った個体が， それとは異なる遺伝子型を持った個体に比べ て, 次世代により多くの遺伝子を残す過程であ る。つまり，自然選択とは一つの遺伝子座にお ける対立遺伝子間の競争のことである。しかし， その場合にも，遺伝子があくまでも表現型とい う形でしか発現できないことは重要である。し かも，一つの遺伝子が必ずしも一つの表現型を 規定するとは限らない。一つの遺伝子がさまざ まな表現型に作用することもあるし（多面発 現),いくつもの遺伝子が集まって一つの表現型 を作ることもある(ポリジーン)。従って，この 場合にも，自然選択が作用するのは，遺伝子が 総合的に発現した表現型（行動）に対してなの だということが重要である。

\section{IV}

ここでもう一度, 話を学習に戻そう。昔から, 学習とは個体の行動の変容であるとされてき た。そして，伝統的学習研究はそのメカニズム を追求してきたといえる。

しかし，筆者は学習の問題をこれまでのよう に個体レベルに留めていたのでは，その本質は 結局は分からないのではないかと思う。なぜな らば, 学習という現象は, 生体の行動と環境と のかかわり合いから生じるものであるが，そも そも生体の行動と環境との間には, 長い進化の 歴史を通じて，既にある深い関係ができあがつ てしまっているからである。

したがって，学習という現象は単なる個体の 行動の変容なのではなくて, その動物が, ある いはその動物種が，既に自分と自分の生態学的 環境との間に持っている行動的関係を, 環境と の絡み合いの結果としてどのように変えて行く かということなのだと思う。変容するのは, 行
動そのものではなくて，行動的関係なのだと筆 者は考えるようになった。

筆者がこのように考えるのは, 学習がその種 の生物学的機能や適応に役立っていることを重 視するからである。なぜなら，そもそもいま存 在している行動が, 過去の進化の歴史の中で, なんらかの生物学的機能との関連において作ら れてきた以上，その行動的関係の変容もまた， なんらかの生物学的機能を有すると考えること は, 当然のことだからである。そして，このよ うに考えるならば，個体レベルで生じた「行動 と生態学的環境との行動的関係の変容」を「学 習」と呼び，種レベルで起こった「行動と生態 学的環境との行動的関係の変容」を「行動の進 化」と呼ぶことができる。

先に, 生物学的制約の一例として自動形成を 挙げた。言うまでもなく自動形成とは,スキナー 箱においてトリの反応とは関係なくキイの照明 と餌の対提示を行なうと，そこにはキイつつき に対する随伴性がないにもかかわらず，やがて トリが自発的にキイ刺激に対してつつきをする ようになる事実である。このことは, 強化の随 伴性のみを行動変容の必須条件としたスキナー 理論にとっては, 致命的な事実であった。

最近, Kamil \& Mauldin（1988）は 3 種のト リ（アオカケス，コマツグミ，ホシムクドリ） が自動形成した反応を，映画に撮って細かく分 析した。それによると，キイ刺激に対してアオ カケスが自動形成した反応型は，ちようどアオ カケスが自然環境において慨であるドングリを むく時に，ハンマーのような嘴で非常に強く餌 を吒く時の反応型とそっくりであった。他方, コマツグミは虫を捕えて食べるトリであるが, 自動形成した反応は，まずキイの方に向いて羽 ばたきを行い，それから突進して行ってキイを つつくという反応であった。また，ホシムクド リは，地中から昆虫を探しだして食べるトリで あるが，自動形成の結果としてでてきた反応型 は，餌を見つけるために土の中を探る時の反応 とそっくりだったのである。つまり，自動形成 
によって発現してきた反応型は, 3 種とも, その 種がもともと持っていた慨を取る時の反応型 だったわけで，これとは別に新しい反応ができ あがったわけではなかった。

先に, 1970 年頃から生物学的制約という形で 伝統的学習理論への挑戦が始まったことを述べ た。このことで, 伝統的学習理論の内部では, 新しい事実を含むための理論修正が始まった が，一方においては，生物学的制約が示した本 来的な姿を目指した新しい形の研究が既に 10 年以上も重衫られ, 同時に, 伝統的(実験室的) アプローチと生態学的(フィールド的)アプロー
チを，新しい形で統合しようとする努力も始め られている。

その一つとして, 近年有力となってきた「強 力の行動調整理論 (behavior regulation theories of reinforcement)」を挙げることがで きよう（例えば, Allison, 1983; Hanson and Timberlake, 1983 ; Timberlake, 1984 ; Staddon, 1983)。これはPremack (1962，1965) の反応説，すなわち，動物が示す諸反応は等価 ではなく, 生起率に基づく行動的偏好階層 (behavior preference hierarchy）として構築され うること, そして, より生起しやすい反応が,

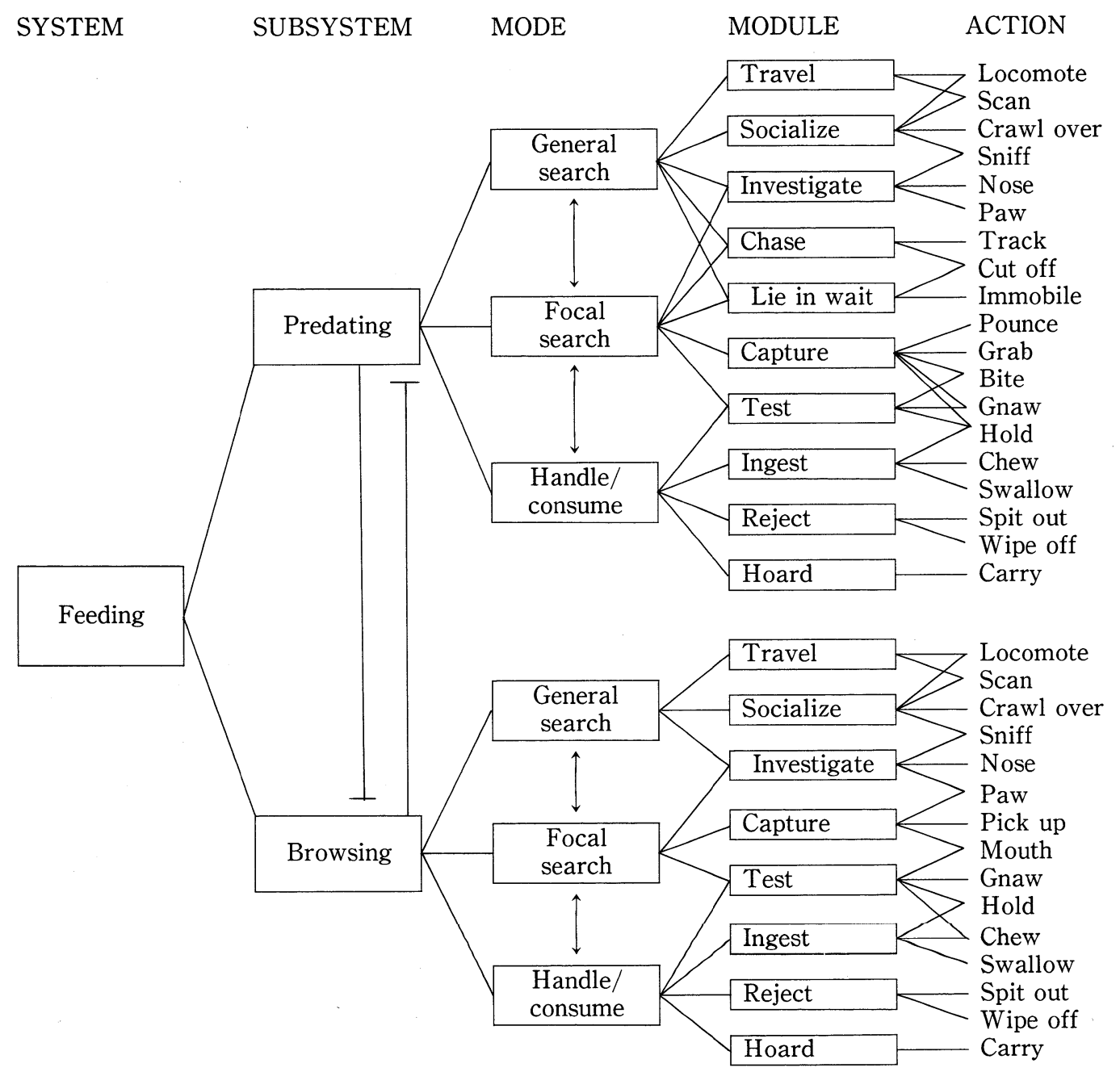

Fig. 2 ラットの摂食行動システムに関する機能的モデル (Timberlake, 1990) 
より生起しにくい反応を強化するという説の展 開といえるが, さらに行動調整理論では, 動物 にはなんらかの調整機構 (regulation mechanisms）があって, 諸反応の配分（response allocation)に当たっては, 生物学的な意味で最 適 (optimal) になるような仕方で，それがなさ れると仮定している。

この行動調整による強化の説明は, 重要な点 で伝統的な強化理論と異なっている。第一は, 動物が示す活動の最適配分そのものが生態学的 環境に適応していると考える点, 第二は, 強化 の効果はこの最適配分が阻害されたり，制限さ れたときに生じるとする点である。そこには， 道具的反応（例えばバー押し反応）と完了反応 （例えば捸食反応）といった質的区別はない。

Fig. 2 は, Timberlake (1990) から引用した ものであるが, これまで伝統的アプローチのも とで行動を研究してきた者と, 生態学的アプ ローチのもとで行動を研究してきた者とが, 今 後一緒になって研究を進めるに当たっては，お 互いが持っている概念枠を共通にして，そこか
ら出発すべきであるとの観点から作られたもの である。一見して分かるように，これは昔 Tinbergen（1951）が作った行動の階層モデルによ く似ているが, ラットの採餪行動 (feeding behavior）に関する機能的なオーガニゼイション モデルである。概念枠の設定に当たっては, 反 応トポグラフィが持つ潜在的な生態学的意味を 保てるように具体的にしたこと, 同時に, 実験 室でのパラダイムを扱えるような抽象性を持た せたと Timberlake は書いている。

ところで，このモデルは，従来の用語で言え ば, 欲求行動の構造と呼んでよいものである。 ただし，機能的な欲求構造 (functional appetitive structur) である。そして，学習はこうし た生体の機能的欲求構造と環境とのかかわり合 いの中で, そのかかわり合いの変容として生じ る。Davey (1989) も behavior system, subsystems, modules, or fixed action patterns, external releasers という形で, ラットの採餌 行動について Timberlake と類似の機能的構造 を発表している。

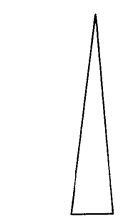

Increasing

Predatory

Imminence

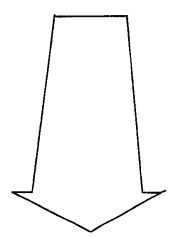

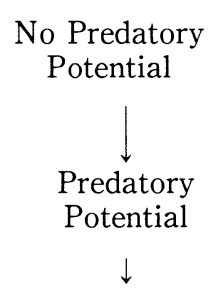

Predator

Detected

Predator

Makes Contact

Predator

Makes the Kill
Preferred Activity

Pattern of Nonaversively

Motivated Behaviors

Pre-encounter

Defensive Behavior

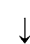

Post-encounter Defensive Behavior

Circa-strike

Defensive Behavior

Point of No Return

Fig. 3 捕食者の切迫度に応じた防衛行動の変化（Fanselow \& Lester, 1988) 


\section{V}

Fig. 3 は, Fanselow \& Lester (1988) から 引用したもので，Fig. 2 が摂食行動に関するモ デルであったのに対して，これは防衛行動に関 するモデルである。捕食者切迫連続体 (predatory imminence continuum) というタイトルが 付けられている。左端の下へ行くほど太くなる 矢印は, 当該動物の捕食者が次第に接近してき たこと，つまり危険が切迫してきたことを示し ており, 次の列はその切迫の具体的な状況を, さらに次の列は切迫状況に対応した当該動物の 行動を示している。

最上段は捕食者の現われる恐れのない状況で ある。動物は摂食，摂水，交尾，養育などの偏 好活動（preferred activity）をしている。とこ ろが，捕食者が現われるかも知れないという状 況（predatory potential）になると，遭遇前防 衛行動 (pre-encounter defensive behavior) が 生じる。そして, 当該動物が捕食者の存在を認 知 (predator detected) すると，ここで遭遇後 防衛行動 (post-encounter defensive behavior) が発現する。ラットの場合では，ここでフリー ジング (freezing response)が起こるが, Bolles （1970）が述べた種特異的防御反応 (SSDR) が 生じるのはこの段階である。

ところで，ラットのフリージング反応とは， ラットをオープンフィールドなどに入れた時 に，ごく普通に観察される反応であるが，従来 は移動行動が抑制された状態として解釈される ことが多かった。しかし, 最近では, フリージ ングとはラットが持っている積極的な防衛行動 の一つであり，ラットにとつて非常に高い生存 価をもった反応だと考えられるようになった。

そして，フリージング反応そのものを研究す る，つまりフリージングは，どういった時に， どのような場所で, どのような刺激で起こるの か，また，例えば回避学習場面においては，条 件刺激との関係で, どの場所でどの時点で, ど のようなフリージングが生じるのか，フリージ
ングは何によって強化され，あるいは抑制され るかといった分脈での研究が盛んになってき た。さらに，こういった研究に伴い，オープン・ フィールド行動に関しても, 従来とはかなり異 なった立場からの解釈がでてくるようになった

(例えば Suarez \& Gallup, 1981)。

さて，当該動物はついに捕食者と遭遇する。 逃走するか, 闘うか。従来の実験室場面での研 究では, 急激な強い電気ショックを与えたとき のラットの爆発的な反応などがこの段階での反 応に当たるだろうが，この段階での捕食者に対 する行動を実験的に調べた研究は少ない（例え ば, Bolles, Riley \& Meissner, 1975)。そして, 捕食者に食べられてしまう時点が, point of no return である。なお，いちばん右側の点線は， 動物が闘争で怪我をした時の回復を示してい る。
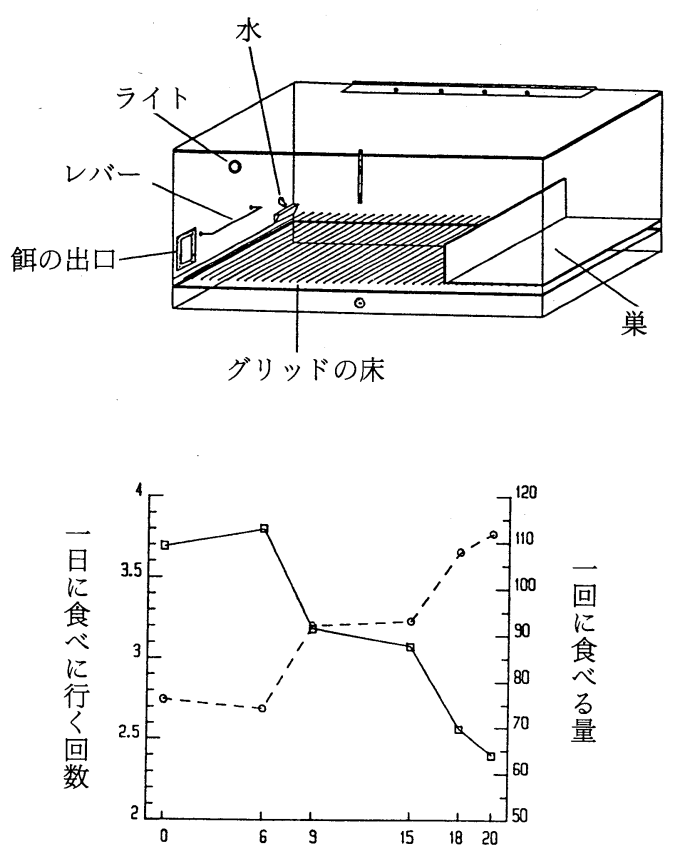

1 日に受ける電撃の回数

Fig. 4 Fanselow \& Lester（1988）が用いた 装置と実験結果 $(\square-\square 1$ 日に 食べに行く回数，○--.--○1回に 食べる量) 
ここで, Fanselow \& Lester （1988）の実 験を紹介したい。これは上述の捕食者切迫連続 体上の捕食者が現われるかもしれない段階で動 物が示す遭遇前防衛行動の特徵を調べようとし た実験である。Fig. 4 に示したチャンバーの右 側が巣で, ここに住むラットが左側のレバーの ところへ行って押すと, 餌が手にはいるように なっている。この中でラットに自由に生活させ, 餌を自由に取りに行かせるわけだが，一日のう ちにラットがグリッドに出てきた時に, 何回か ランダムに電気ショックを与える。その回数が 右側の図の横軸に示されている。

図を見ると，まったく電気ショックを受けな い時には, ラットは一日に 3.7 回食べに行き, 一回に 75 個ほどのペレットを食べる。ところ が, グリッドで電気ショックを受ける回数が増 えてくると, 餌を食べに出る回数が減り, 20 回 ショックを受けた場合には，一日に 2.4 回まで 下がってしまう。ところが，一回に食べる量は 電気ショック回数に応じて次第に増え, 20 回 ショックの場合には 110 個以上も食べるように なる。要するに，ラットは巣の外が危ないと思 うと, 出かける回数を減らすかわりに, 一回に 食べる量を増やすのである。回数と量を掛ける と, 一日の摂取量はほとんど同じであることが 分かる。

先ほど筆者は, 学習を行動と生態学的環境と の関係の変容として捉えることを提案したが, この Fanselow たちの実験は, 防衛行動の研究 として優れているばかりでなく, 新しい夕イプ の学習の研究としても大変興味ある研究である と思う。

\section{VI}

近年, 行動生態学 (behavior ecology) と呼 ばれる分野での研究が盛んになってきた。同じ く動物行動を研究する我々にとっては, 脅威を 感じる部分がある。従って, 行動生態学で用い られているいくつかの研究スタイルを紹介した い。Fig. 5 と 6 は, Krebs \& Davies (1981) か
ら抜粋したものである(この本は, 1987 年に改 訂 2 版がでた)。

Fig. 5 に示した研究は, Zach (1979) がカナ ダの西海岸に生息するカラスの群れの採餉行動 を研究したものである。このカラスたちは，引 潮の時に海中から大きな貝を拾い, 近くの岩の ある所まで飛んで行って, 高いところから落と して割って食べるということをする。

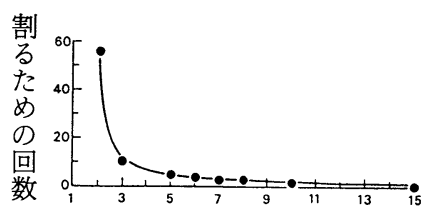

落す高さ (m)

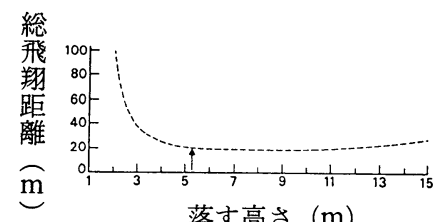

落す高さ (m)

Fig. 5 カラスの採餌行動に㧍ける最適理論の 適用 (Zach, 1979)

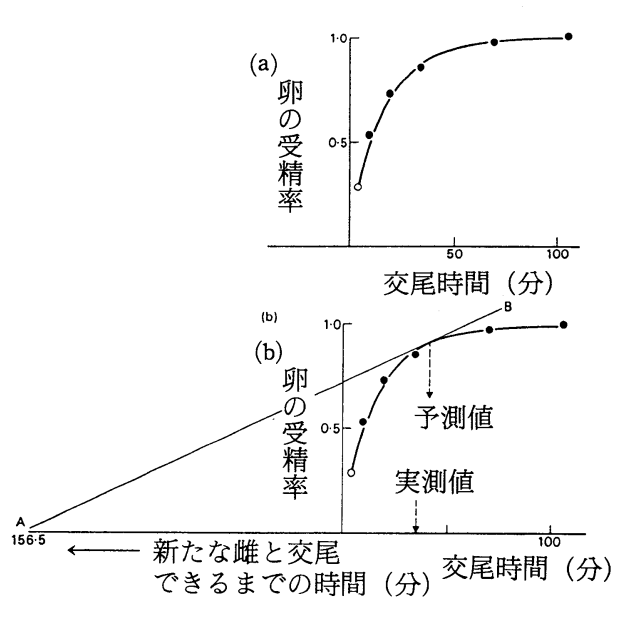

Fig. 6 フンバエの配偶行動における最適理論 の適用（Parker, 1978) 
ところがZ Zach が観察したところでは, カラ スたちはいつもだいたい同じ高さから貝を落と した。なぜだろうか。そこで, Zach は自分で貝 をいろいろな高さから落として，何回で割れる かを実験してみた。その結果が, Fig. 5 の上の方 の図である。高さ $2 \mathrm{~m}$ からでは, 60 回近くも落 とす必要があるが, $5 \mathrm{~m}$ の高さから落とせば 3 回ほどで割れる。しかし, あまり高い所から落 とすと, 1 回で割れるかわりに貝が粉々になっ て中身を探すのがやっかいであった。

こうした結果から，貝を割るためのカラスの 総飛翔距離を, 飛び上がる高さとの関係から計 算してみたところ,下の図のようになった。そ して, 実際にカラスが飛び上がる高さ $(5.2 \mathrm{~m})$ は, 理論的に最も効率のいい高さに近かったの である。ここでいう効率とは，貝を食べること で得られる利益（エネルギー）と飛翔に必要な 出費（エネルギー）との関係から算出された。

Fig. 6 は Parker (1978) がフンバエの配偶行 動に関して行なった研究である。まず(a)から説 明すると, 横軸が交尾時間で, 縦軸が受精率で ある。つまり, 交尾時間が長いほど, 受精率が 高くなって行く。これは実験によって確かめら れている。ところが, フンバエの雄の戦略, つ まり自分の子をできるだけ多く残すという戦略 からすれば，1匹の雌にずっと留まっているよ りも, ある程度の受精率に達したところでこの 雌から離れ, 別の雌を見つけて交尾した方が得 である。

そこで, 実際に雄が次の雌を見つけるまでの. 時間を調べたところ，平均して 156.5 分である ことが分かった。そこで, この 156.5 分を上図 の横軸の左に付け加えて, 卵の受精率のカーブ へ接線 A-B 引くと, 接点はそこで雄が交尾中 の雌から離れて, 新しい雌を求めて飛び立った 方が結局は自分の子を残す効率がよくなる時間 である。そして, 実測值はだいたいこの予測值 と一致した(b)。

最近の行動生態学の研究では, こうしたス夕 イルの研究が多いが, それらはいわゆる最適理 論（optimality theory）に立脚している。それ は, 行動を利益 (benefit) と出費 (cost) のつ りあい（trade-off）から考えて行く理論である。 その場合の通貨としてはエネルギーが考えられ ている。最近のこうした文献を読むと, 経済学 の論文かと思うほどに, 利益とか, 出費とか, 効率とかいう言葉が飛び出してくる。

そして特に最近では, 採慨行動 (foraging behavior）についての研究が増えてきた (Kamil \& Sargeant, 1981)。例えば，ミツド リがある餌場（パッチ）で花から蜜を吸ってい る状況を考えてみよう。そのパッチの花は次第 に蜜を吸われていくので, 採䬺効率は悪くなっ て行く。従って, ミッドリはどこかの時点でそ のパッチをあきらめて, 次のパッチへ行った方 がいい。しかし, 次のパッチへ行くためにはエ ネルギーを消費せねばならない。では，どの時 点でいまの餌場を離れたらいいのか。

それを予測するためには, まずそれぞれの パッチでは花がどれほど潤沢にあるのか, 花は どのように吸われて行くのかを実測する。次に トリが次のパッチを見つけるまでの時間を実測 する。そして, さきほどのフンバエの交尾の場 合のように接線を引いて, パッチを離れるまで の時間を予測し, それが実測值とどの程度一致 するかを調べるのである。

さらに最近になると, ラットやリスのように 巣に餌を持って帅る動物や，子を育てるために 巣に餌を持って帰らなければならない動物を, central place forager と呼んで, それらの採餌 行動を研究することが流行りになってきた

(Lima, Valone \& Caraco, 1985; Lima \& Valone, 1986 ; Phelpes \& Roberts, 1989 な ど)。

これらの研究では, 餌場で餌を見つけるまで の出費, 餌を巣まで持って帰るための出費, さ らには，途中で捕食者に遭遇する出費などを考 えた時に, いったい動物はどれくらいの量の餌 ならばその場で食べた方が得なのか，それとも 持って帰った方が得なのか。それはどういう密 
度で餌がある時か, 捕食者がいる時といない時 ではどうかなどを予測して，実測值と比較する といった方法がとられている。筆者の研究室で も, 中津山（1991）が central place forager と してのラットの採餌行動を, 餌場の数, 餌場ま での距離, 餌の量を変数として, 実験室と野外 フィールドの両方において研究した。

\section{VII}

さてここで，上で述べたこととの関連から， 筆者が研究してきたことの一部を紹介させて頂 きたい。

筆者が, 現在 Tsukuba 情動系ラット (Fujita, 1984）と呼ばれる 2 種類の系統（近交系）を作 るために，情動性に関する選択交配の実験を始 めたのは 1972 年であった。Fig. 7 は,この時の 選択交配の基本的な発想を示す図である。

まず，ラットは地下に穴を掘って生活する動 物であるという認識から出発した。そして，穴 の中には慨はないから，慨を得るためにはラッ トは穴の外へ出て行かねばならない。ところが, ラットは地上にいる時に, 捕食者によってかな り食べられる動物である。このため, ラットは
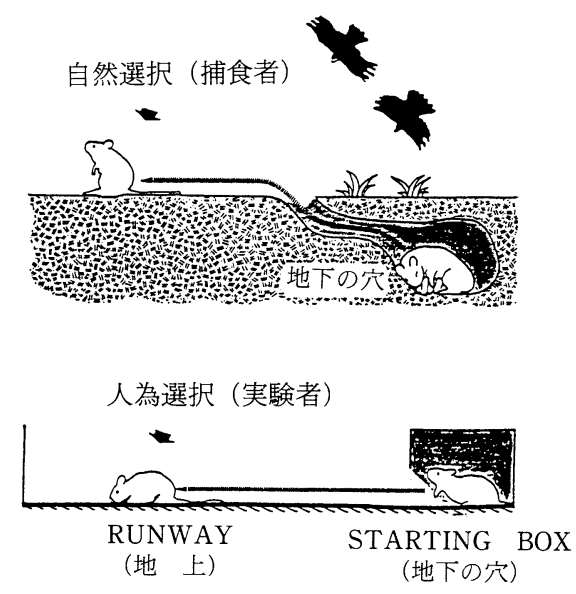

Fig. 7 情動反応性に関する自然選択と人為選 択（ランウェイ・テスト）（藤田，1972）
穴から外へ出て行く時には, 出て行くか, 出て 行かないかで, 相当, 躊躇する。また, 地上に 出ている時にも, ちょつとした環境の変化に対 してフリージングをしたり, 急いで手近の穴に とびこんだりする。

従って, こうした生態学的な場面で示される ラットの行動こそが, 長い自然選択の結果とし て現在のラットに備わっている情動行動なので はないか。それならば，ラットの生態学的状況 を実験室においてシュミレイトすれば, 現在の ラットが持つ情動性の高低（個体差）を測定で きるだろう，と考えたわけである。

こうして考案したのが, Fig. 8 に示したラン ウェイと呼ぶ非常に簡単な装置であった。出発 箱はラットの穴の中をシミュレイトしているの で暗くしてある。走路部分は地上と考えるので 明るくしてある。出発箱から走路部分への出口 は穴から地上への出口に相当する。そして, 出 発箱から躊躇なく走路部へ出てフリージングす ることもなく歩き回るラットを情動性が低いと 考え, 出発箱から走路部へなかなか出られない でフリージングばかりしているラットを情動性 が高いとした。

そして, 両極端の行動特徴を示したラットを それぞれ選択交配して行ったのであるが，行動 に関する自然選択とは，ある行動をした個体で は子が残り，そうでない個体では子が残らない ということである。したがって筆者は，いわば 自然になり代わって, ある行動をした個体には

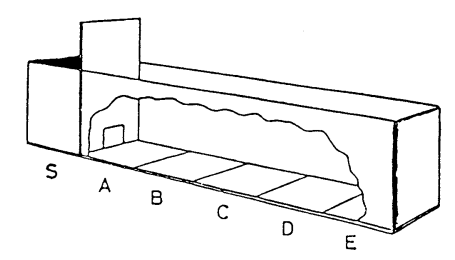

Fig. 8 Tsukuba情動系ラットの選択交配に 用いたランウェイ装置(藤田, 1972) $\mathrm{S}=$ 出発箱, $\mathrm{A} \sim \mathrm{E}=$ 走路部 
子を残すことを許し，そうでない個体には許さ ないという仕事を何世代も続けたことになる。

Fig. 9 がこの選択交配の経過である。この図 には 35 世代までしか載っていないが，現在，50 世代まで進んでいる。一見して分かるように， 情動性の高低に関する系統は, 選択交配の結果 として，きれいに分離して行った。そして，こ の Tsukuba 情動系ラットについては, 種々の 情動場面への対処行動様式の相違ばかりでな く, 様々の反射や初期行動の発達, 貯蔵行動, 攻撃行動, 社会行動, 各種の学習行動, 脳内生 化学物質などの相違,さらには各種薬物の効果, 両系統の遺伝構造の分析, 遺伝子座数の推定等, すでに 60 以上の研究が報告されている（藤田 ら, 1982)。

Fig. 10 は, 我々が筑波大学に持っているラッ ト用野外フィールドである。かなり大きいもの で，作ってから 8 年の歳月が流れている。この フィールドに Tsukuba 情動系ラットを投入し て，雨が降ろうが，雪が降ろうが，そのまま自 然繁殖にまかせたのである。ラットは地下に穴 を掘って生活し繁殖して行った。我々は，この 野外フィールドでの研究から，ラットの社会行 動をも含めて，様々の行動や繁殖経過に関して 実に多くのことを学んだ（藤田，1984b，1986，
1989 ：藤田ら，1990）。

とはいえ，野外フィールドで分かったことだ けでは十分とは言えなかった。質的なことは分 かっても，量的なことを明確にしにくかったか らである。従って，フィールドで分かったこと を実験室へ持ち込んで，いわば大事な側面だけ をカットアウトして，その側面を実験によって 詳しく調べることが必要となってきた。野外 フィールドで分かったことと，実験室に持ち込 んで分かったことを比較することが重要であっ た。

その一例を示そう。Fig. 11 は, 我々の実験室 で穴掘り行動を調べるために使っている装置で ある。Tsukuba 情動系ラットのうちの Tsukuba 高情動系 (THE) と呼ばれる臆病な系 統は，Tsukuba 低情動系 (TLE) と呼ばれる大 胆な系統に比べて，野外フィールドに投入され ると早く穴を掘り，土を沢山かきだす。このこ とは野外フィールド研究の初期から分かったの だが, 野外フィールドでは個体識別が難しいし, 量的なことも測定しにくい。そこで，実験室に 人工的な装置を作って一匹ずつ実験したわけで ある。その結果, 北岡・藤田（1988）が示した ように，臆病な方の系統は，どの個体も野外 フィールドで分かったのと同じように，早く穴

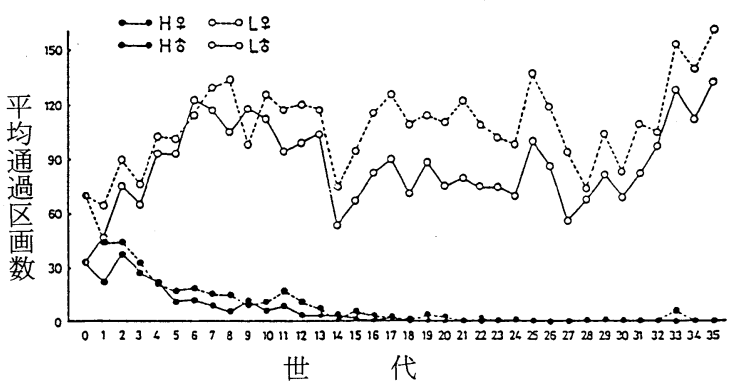

Fig. 9 Tsukuba情動系ラットにおける選択 交配の経過（藤田，1984） H : Tsukuba高情動系，L：Tsukuba低情 動系

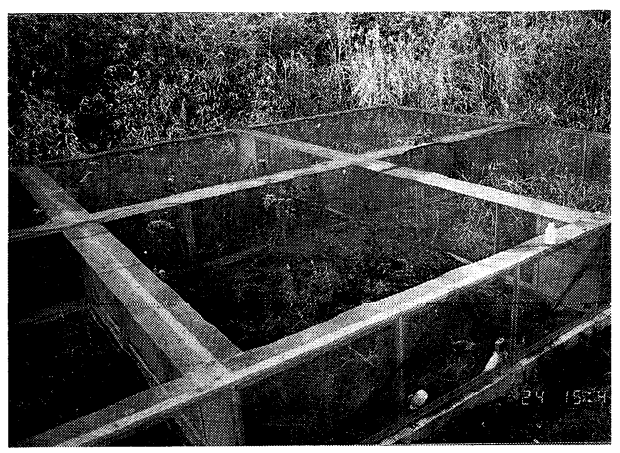

Fig. 10 ラット用野外フィールド(藤田，1984） 


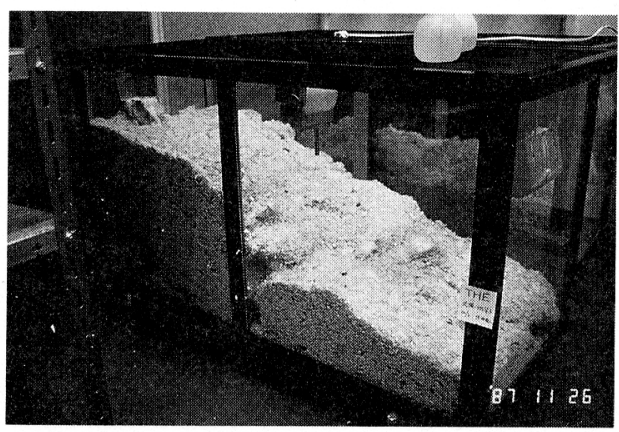

Fig. 11 ラットの穴掘り行動を測定するため の装置。Tsukuba高情動系ラットは特 徵的な堆積を作る(北岡・藤田, 1988)。

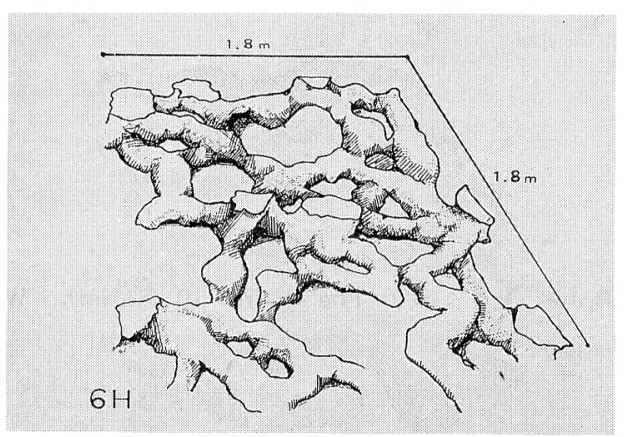

Fig. 12 ラットが野外フィールドの地下に 作った穴

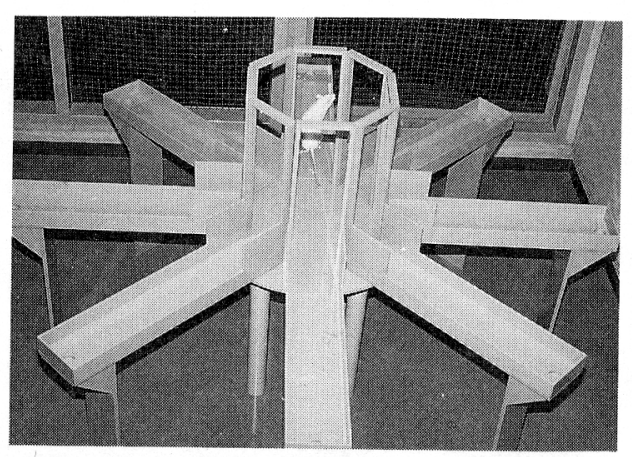

Fig. 13 筑波大学心理学系において用いてい る八方向型放射状迷路
を掘り，長いトンネルを作り，土を沢山かき出 して山のような堆積を作るという特徵を示した のであった。

Fig. 12 は, 野外フィールドに作られた穴に石 膏を流し込んで固め, それを掘り出して写生し たものである。ただしこの図は，一つのフィー ルドの 4 分の 1 だけを示している。穴の構造は このように複雑で, 途中が膨らんでいたり, 階 層になっていたり，立体交差していたりする。 膨らんだ部分を割ってみると，中にあるものか ら，ここは育児用の巣であるとか，貯蔵場であ るといったことが分かってきた。ラットはこの ような迷路の中で生活しているのである。

他方, Fig. 13 は, 我々の研究室で使っている 八方向型の放射状迷路である。放射状迷路は Olton(1979)が考案した装置であるが，筆者は， この装置はラットの生態学的状況にたいへんう まく適合した装置だと思っている。この装置で は各迷路の先端に餌を置き, ラットに自由に選 択をさせるのだが，ラットはかなりでたらめな 選択をしながらも，次々とまだ行っていないと ころを間違いなく選択して行く。

かって筆者は, 迷路の本数を増して 24 本にし ても, ラットは間違えないという報告を読んだ 時には，にわかには信じ難かった。ラットがそ んなに頭がいいはずはないと思っていたからで ある。ところが，我々のところで実際に実験を してみると, ラットはこの迷路を極めて早く, 間違いなく覚えた。考えてみると, ラットとい う種はあのように複雑な迷路を地下に作って, 何世代となくその中で生活してきたのである。 この放射状迷路ぐらいなら，たやすく覚えるの は当然なのであった。

\section{VIII}

最後に，いままで述べたことを踏まえて，こ れからの行動研究への提言を述べさせて頂きた いと思う。

第 1 は, 行動研究に当たっては, 基本的に生 態学的発想を持つことが重要であると思う。つ 
まり，行動の適応・進化という発想(Why Question）を持つことが必要であろう。少なくとも， 自分は生き物を扱っているのだ，換言すれば， 物を扱っているのではないということをはっき りと認識したうえで, 研究を出発させるべきだ と思う。

第 2 は，自然環境における行動を重視するこ とである。たとえ自分では自然環境における観 察や実験ができなくても, 自然環境における動 物の行動に関する知識を持ち，それを尊重する ことが重要である。少なくとも, 自分が使う種 についてはそうあってほしいと思う。

第 3 は, 生態学的に意味のある行動を研究す ることである。ここでいう生態学的に意味のあ る行動とは, 個体の維持と, 種の保存を支える 行動のことである。具体的には, 前者には採餌 行動や捕食者への防御行動が含まれ, 後者には, 繁殖行動や養育行動が含まれる。

第 4 は, 生態学的に意味のある状況を実験室 において上手にシミュレイトすることである。 これは動物行動を研究する心理学者にとって は, 特に重要なことだと思う。なぜならば, 我々 心理学者の知りたいことは, フィールドでの研 究だけでは, 必ずしも満足の行くほど十分には 手に入らないからである。従って, 多くの側面 を統制したうえでの実験が必要となってくる。 フィールドでの生態学的状況を, 実験室におい てどのように上手にシミュレイトできるか。こ こが, 心理学者としては, いい研究か, そうで ないかの分かれ道になると思う。

第 5 は, 異なる種の行動を, 生態学的観点か ら比較することである。筆者は, 行動の比較と いうことは，ただやみくもに行なっても意味が ないと思っている。まずは, 近縁種の行動を比 較するところから出発すべきである。その場合 にも, 生態学的観点から比較することが特に重 要であろう。

以上, 勝手なことを述べさせて頂いた。40 年 近く動物行動を研究してきた者の感想として, 受け取っていただければ幸いである。

\section{REFERENCES}

Alcock, J. 1975 Animal behavior : an evolutionary approach. Sunderland Mass: Sinauer.

Allison, J. 1983Behavioral Economics, New York. : Praeger.

Bennet-Clark, H.C. 1970a A new French mole cricket, differing in song and morphology from Gryllotalpa gryllotalpa L. (Orthoptera: Gryllotalpidae). Proceedings of Royal Entomological Society of London, 39, 125132.

Bennet-Clark, H.C. 1970b The mechanism and efficiency of sound production in mole crickets. Journal of Experimental Biology, 52, 619-652.

Bolles, R.C. 1970 Species-specific defense reactions and avoidance learning. Pschological Review, 77, 32-48.

Bolles, R.C. 1985 The slaying of Goliath : What happen to reinforcement theory. In T.D. Johnston \& A.T. Pietrewicz (Eds). Issues in the ecological study of learning. Lawrence Erlbaum Associates, pp. 387-400.

Bolles, R.C., \& Beecher, M.D. 1988 Evolution and learning. Lawrence: Erlbaum Associates.

Bolles, R.C., Riley, A.., \& Meissner, D.J. 1975 Defensive behavior of the rat encountering Mustelaputorius. Cited in M.S. Fanselow \& L. S. Leser (1988) A functional behavioristic approach to aversively motivated behavior : Predatory imminence as a determinant of the topography of defensive behavior. In R.C. Bolles \& M.D.Beecher (Eds), Evotution and learning, Lawrence Erlbaum Associates, pp. 185-212.

Brown, P., \& Jenkins, H.M. 1968 Autoshaping of the pigeon's keypeck. Journal of the Experimental Analysis of Behavior, 11, 1-8.

Davey, G. 1989 Ecological learning theory. 
Routledge.

Dewsbury, D.A. 1990 Contemporary issues in comparative psychology. Sinauer Associates.

Fanselow, M.S., \& Lester, L.S. 1988 A functional behavioristic approach to aversively motivated behavior: Predatory imminence as a determinant of the topography of defensive behavior. In R.C. Bolles \& M.D. Beecher (Eds), Evolution and learning, Lawrence Erlbaum Associates, pp. 185-212.

藤田 統 $1983 \mathrm{a}$ 生得的行動 系魚川直祐編 「現代基礎心理学 9 発達(1)系統発生」, 東京大 学出版会, pp.15-39.

藤田 統 1983 b 行動の適応と進化 永野重 史・依田 明編「発達心理学への招待(7)文化 のなかの人間」, 新曜社, pp.256-272.

Fujita, O. 1984 "Tsukuba Emotionality": New selected rats. Rat News Letter, 13, 31.

藤田 統 1984 a 行動理論モデルにおける適応 の意義 日本心理学会第 48 回大会特別シン ポジウム, 日本心理学会第 48 回大会発表論文 集, S8.

藤田 統 $1984 \mathrm{~b}$ 行動遺伝学的に作られた高・ 低情動反応系ラットの自然環境場面における 適応性の研究 昭和 $57 \cdot 58$ 年度科学研究費補 助金 (一般研究 B) 研究成果報告書, pp.1-25.

藤田 統 1985 心理学におけるフィールド研究 の意義について 日本心理学会 第 49 回大 会発表論文集, 590 .

藤田 統 1986 行動遺伝学的に作られた高・低 情反応性系ラットの自然環境場面における行 動の分析 昭和 $59 \cdot 60$ 年度科学研究費補助金 (一般研究 B) 研究成果報告書, pp.1-37.

藤田 統 1989 行動の個体差の発現機序に関す る行動遺伝学的・生理生化学的・生態学的研 究 昭和 $61 \cdot 62 \cdot 63$ 年度科学研究費補助金 $($ 一 般研究 B）研究成果報告書, pp.1-238.

藤田 統・加藤 宏 1983 a 行動研究に扔ける 遺伝の意味について一行動遺伝学の歴史と展 望一動物心理学年報, 33, 49-65.
藤田 統 ・加藤 宏 $1983 \mathrm{~b}$ 行動遺伝学におけ る新しい潮流一適応への傾斜一筑波大学心理 学研究, 5, 25-35.

藤田 統 - 加藤 宏・安念保昌 - 増井誠一郎 - 北 岡明佳・中津山英子 1990 Tsukuba 情動系 ラットの野外フィールドにおける 4 年間の個 体数の推移とそれに関連する雄の性行動 筑 波大学心理学研究, 12, 37-45.

藤田 統・中村則雄・宮本邦雄 1982 選択交配 により作られた高・低情動反応性系ラットの 行動比較 浜 治世編集「基礎と臨床の心理 学 II 行動理論と個体差」, 誠信書房, pp. 156-174.

Garcia, J., \& Koelling, R. 1966 Relation of cue to consequence in avoidance learning. Psychonomic Science, 4, 123-124.

Hamilton, W.D. 1964 The genetical theory of social behaviours, I, II. Journal of Theoretical Biology, 7, 1-52.

Hanson, S.J., \& Timberlake, W. 1983 Regulation during challenge : a general model of learned performance under schedule constraint. Psychological Review, 90, 261-282.

Johnston, T.D., \& Pietrewicz, A.T. 1985 Issues in the ecological study of learning. Lawrence Erlbaum Associates.

Kamil, A. C., \& Sargeant, T.D. 1981 Foraging behavior: Ecological, ethological, and psychological approach. New York: Garland STPM Press.

Kamil, A.C., \& Mauldin, J.E 1988 A comparativeethological approach to the study of learning. In R. C.Bolles \& M.D.Beecher (Eds), Evolution and learning, Lawrence Erlbaum Associates, pp.117-133.

北岡明佳・藤田 統 1988 ラットとマウスの穴 掘り行動に及ぼす情動性・性・照明条件の効 果 動物心理学年報, 38, 93-106.

Krebs J.R. \& Davies N.B. 1978 Behavioural Ecology : an Evolutionary Approach. Black- 
well Scientific Publications, Oxford.

Krebs, J.R., \& Davies, N.B. 1981 An introduction to behavioural ecology. Blackwell Scientific Publications, Oxford.

Lima, S.L., \& Valone, T.J. 1986 Influence of predation risk on diet selction: a simple example in the grey squirrel. Animal Behaviovr, 34, 536-544.

Lima, S.L., Valone, T.J., \& Caraco, T. 1985 Foraging-efficiency-predation-risk trade-off in the grey squirrel. Animal Behaviour, 33, 155165.

Logue, A.W. 1979 Taste aversion and the generality of the laws of learning. Psychological Bulletin, 86, 276-296.

LoLordo, V.M. 1979 Selective associations. In A. Dickinson, \& R.A.Boakes (Eds). Mechanisms of learning and motivation. Lawrence Erlbaum Associates.

中津山英子 1991 ラットの野外生活場面と実験 室場面における採餌行動に及どす慨の大き さ・採餌距離の影響 筑波大学心理学研究科 修士論文

Olton, D.S. 1979 Mazes, maps, \& memory. American Psychologist, 34.583-596.

Parker, G.A. 1978 Searching for mates. In J.R. Krebs \& N.B. Davies (Eds) Behavioural Ecology : an Evolutionary Approach, Blackwell Scientific Publications, Oxford, pp, 214244.

Phelpes, M. T., \& Roberts, W.A. 1989 Centralplace foraging by Rattus norvegicus on a radial maze. Journal of Comparative Psychology, 103, 326-338.
Premack, D. 1962 Reversibility of the reinforcement relation. Science, 136, 255-257.

Premack, D. 1965 Reinforcement theory. In D. Levine (Ed), Nebraska Symposium on Motivation, vol.13, Lincoln, Ne.: University of Nebraska Press.

Seligman, M.E.P. 1970 On the generality of the laws of learning. Psychological Review, 77, 406-418.

Staddon, J.E.R. 1983 Adaptive Behavior and Learning, Cambridge : Cambridge University Press.

Suarez, S.D., \& Gallup G.G. 1981 An ecological analysis of openfield behavior in rats and mice. Learning and Motivation, 12, 342-363.

Timberlake, W. 1984 Behavior regulation and learned performance: some misapprehensions and disagreements, Journal of the Experimental Analysis of Behavior, 41, 355-375.

Timberlake, W. 1990 Natural Learning in laboratory paradigms. In D.A. Dewsbury (Ed.) Contemporary issues in comparative psychology, Sinauer Associates, pp. 31-54.

Tinbergen, N. 1951 The study of instinct. Oxford University Press.

Tinbergen, N. 1963 On aims and methods of ethology. Zeitschrift für Tierpsychologie, 20 , 410-429.

Wilson, E.O. 1975 Sociobiology: The new synthesis. Cambridge: Harverd University Press.

Uack, R. 1979 Shelldropping: decision making and optimal foraging in Northwestern corws. Behaviour, 68, 106-117. 